Article

\title{
Customer Knowledge Management in SMEs Facing Digital Transformation
}

\author{
Francesco Castagna ${ }^{1}$, Piera Centobelli ${ }^{1}$, Roberto Cerchione ${ }^{2, *}$, Emilio Esposito ${ }^{1}$, \\ Eugenio Oropallo ${ }^{1}$ and Renato Passaro ${ }^{2}$ \\ 1 Department of Industrial Engineering, University of Naples Federico II, P.le Tecchio 80, 80125 Naples, Italy; \\ francesco.castagna@unina.it (F.C.); piera.centobelli@unina.it (P.C.); emilio.esposito@unina.it (E.E.); \\ eugenio.oropallo@unina.it (E.O.) \\ 2 Department of Engineering, University of Naples Parthenope, Centro Direzionale di Napoli, Isola C4, \\ 80143 Naples, Italy; renato.passaro@uniparthenope.it \\ * Correspondence: roberto.cerchione@uniparthenope.it
}

Received: 17 March 2020; Accepted: 4 May 2020; Published: 10 May 2020

check for updates

\begin{abstract}
This paper provided a novel definition of customer knowledge management (CKM) as the logical intersection of customer relationship management (CRM) and knowledge management $(\mathrm{KM})$. The main aim was to investigate the digital technologies supporting small and medium enterprises (SMEs) operating in creative industries in their customer knowledge management strategies. To achieve this aim, a survey involving 73 handicraft and/or retail SMEs operating in luxury jewelry industry was conducted. The survey results pointed out that in a few years the scenario has changed and that surveyed SMEs make more intensive use of traditional technologies supporting customer knowledge management processes rather than more innovative digital technologies, which are also cheap and easy to use. This finding showed the difficulties of SMEs operating in creative industries to be responsive to the rapid technological changes that are affecting CKM, as well as the lack of support from information technology vendors in the decision-making process for choosing adequate digital systems.
\end{abstract}

Keywords: creative industry; customer knowledge management (CKM); customer knowledge management systems (CKMSs); customer relationship management (CRM); digitalization; digital technologies; small business; survey

\section{Introduction}

Recent research contributions revealed that enterprises are adopting digital technologies to improve their knowledge management processes that in turn have an impact on innovation, the market and financial performance [1-3]. The digital revolution has questioned the extant innovation and organisational learning theories [4]. For instance, Nambisan et al. (2017) [5] analysed how organisational axioms may be changed by the rise of digitalisation to renew a knowledge base and improve innovation performance. This evolving technological and organisational environment has required firms to improve their knowledge management (KM) processes (e.g., acquisition, storage, transfer) since a focus on internal knowledge or an exposure to external knowledge are not sufficient to increase innovativeness [6-10].

Meanwhile, information systems scholars found evidence that digitalization has a pivotal role for enabling external knowledge acquisition activities [11]. Nowadays firms therefore are focusing their efforts to digitalise their innovation processes [5], especially for $\mathrm{KM}$ objectives. In fact, the established organisational routines and processes affecting KM strategies are likely changing together with the direction being identified by the adoption of digital solutions for product and process innovation 
(e.g., advanced business analytics, digital platforms, machine learning). For instance, the processes of knowledge acquisition, storage and transfer are changing in terms of the amount of data and information to be managed due to the emergence of appropriate digital infrastructures. Similarly, firms adopting digital solutions have to acquire and transform different types of external knowledge compared to non-digital firms, thus requiring the opportunity to use new knowledge management systems (KMSs) [12]. This means that digital innovation has created a new fluidity in innovation processes, however it is also asking firms to rethink the ways they can explore and exploit knowledge flows, and the way they can leverage on the adoption of digital platforms, infrastructures and artefacts [13-16].

In recent years creative industries have acquired a relevant role in European countries where small and medium enterprises (SMEs) represent a vast majority of all companies [17,18]. As for the epistemological perspective, the knowledge created in firms operating in creative industries is mainly tacit in nature [19]. As for the ontological perspective, in the context of SMEs operating in creative industries, customer knowledge is mainly embodied in organizational members and embedded in specific practices, know-hows and routines [20]. Despite the fact that previous authors have shown growing interest in investigating knowledge management processes in the context of creative industries, there is a lack of empirical papers aimed to investigate customer knowledge management issues [21,22].

Customer knowledge management is somewhat unique in the field of knowledge management [23]. Customer knowledge management integrates the set of organisational practices and dynamic skills related to the creation, storage and transfer of knowledge about the customer [24] to gain a sustainable competitive advantage in the market [25] and improve business efficiency through specific development strategies [26]. Nevertheless, although knowledge management has been studied in different fields and customer knowledge management has been investigated as an antecedent of sustainable and competitive success, further research is needed to analyse the role of customer knowledge management in the creative industry domain $[27,28]$. In this industry, managing customer knowledge through collaborative innovation paths has a critical role in achieving successful innovation practices [24]. Furthermore, Prahalad and Ramaswamy (2004) investigated the role of customer collaboration and enabling technologies to allow successful organisations to learn from their customers' needs, how to meet their demands and thus improve performance [29]. In this context, despite previous contributions focusing on specific relational tools, marketing tools and search optimisation tools, there is a clear need for a comprehensive overview of the digital technologies used by SMEs to support their customer knowledge management strategies. Within this evolving scenario, technology dynamics and digital transformation are increasingly offering to firms, in particular to SMEs, new digital technologies that are low cost, ease-to-use and effective [30-34].

With these premises, the main aim of this paper was to investigate the digital technologies supporting SMEs operating in creative industries in their customer knowledge management strategies. To achieve this aim, it is necessary to distinguish between different categories of technologies, namely relational tools, marketing tools and search optimisation tools.

The article is structured in six sections: the introduction (Section 1), the framework (Section 2), unit of analysis (Section 3), methodology (Section 4), presentation of findings (Section 5) and the conclusions and implications (Section 6).

\section{Framework}

Customer knowledge management represents a research area at the intersection between knowledge management and customer relationship management $[35,36]$.

The main objective of the literature search was to analyse the state-of-the-art on customer knowledge management before to moving to the digital technologies supporting customer knowledge management (CKM) strategies in order to identify potential gaps [37-39].

Customer knowledge management integrates the set of organisational practices and dynamic skills related to creating, conserving and transferring knowledge about the customer [24]. Previous research 
highlights that customer knowledge management strategies pertain primarily to the socialization processes with customers that have a critical role in gaining a competitive advantage in the market $[25,40]$. Similarly, Srikantaiah et al. (2000) investigated how managing customer knowledge is crucial to achieve a better and more timely design of new products and services, competitive intelligence, customer commitment and loyalty, as well as a synergy of collaboration [41]. On the contrary, Butler (2000) highlighted the lack of attention paid to customer knowledge stating that customers know more about the organizations they do business with than the business knows about its customers [42]. Even though all businesses recognize that they are nothing without their customers, they rarely fully capitalize on the customer knowledge that their employees informally collect, avoiding a deep customer relationship which is one of the business strategies that organizations must adopt for competitive gains. Customer relationship focuses on obtaining information on customer's needs in order to improve customer satisfaction and increase its buying behaviour; once this customer relationship is achieved, the customer will avoid the high costs of switching to other businesses [40]. Davenport et al. (2001) focused on three main elements of customer knowledge: (1) company efforts to capture customer knowledge, (2) marketing activities, and (3) customer relationship management (CRM) [43]. In more detail the authors presented a comprehensive review of the efforts that an organization made to capture customers' knowledge focusing on the value of personal interactions. However, there is again a lacuna about the methods and tools to obtain this kind of knowledge. An important step was reached by Gibbert (2002) that identified five different styles of customer knowledge management depending on different sectors [44]: (1) prosumer (Toffler, 1980), where the customer could fill the dual roles of producer and consumer (e.g., Quicken; IKEA) [45]; knowledge in this case is more explicit. (2) Team-based co-learning (Gibbert, 2002), where inter-linkages are established with the customer base and standing by their interactive joints, the organization becomes attractive for many other companies for its learning performance standing by its own customer interactions (e.g., Amazon.com; Xerox, Holcim, Mettler, Toledo) [44]; knowledge in this case is both explicit and tacit. (3) Mutual innovation (Thomke and Hippel, 2002), where innovations come not from within the organization but from end-users (e.g., Silicon Graphics, Ryder) [46]; knowledge in this case is more tacit. (4) Communities of creation (Sawhney and Prandelli, 2000), where innovations come from end-users but in contrast to mutual innovation, it is not possible to collect end-user ideas and each customer has to interact with the others and the organization has to elaborate together the innovation knowledge (e.g., Microsoft; Sony; eBay, Holcim) [47].; in this case the knowledge is also more tacit. (5) Joint intellectual property (Gibbert, 2002) where as in mutual innovation, the organization has to collaborate with customers even though intellectual property does not reside in the organization but is 'owned' partly by the customers (e.g., Skandia assurance) [44]; knowledge in this case is more explicit.

Each type of customer knowledge has specific characteristics and requires specific tools to be achieved. At this point, it results as important to highlight the point of view of Rowley (2002) that formalized how recent technological tools facilitate the knowledge transfer, acquisition and elaboration [48]. Customer data can be collected as customer feedback, during transactions and through cookies and web-server logs. At this point there is no shortage of data in e-business, but it is necessary to clear and elaborate these data to achieve the right knowledge [48].

Managing customer knowledge through collaborative innovation paths has a critical role in achieving successful innovation practices [24]. Furthermore, Prahalad and Ramaswamy (2004) investigated the role of customer collaboration and enabling technologies to allow successful organisations to learn from their customers' needs, how to meet their demands and thus improve performance [29]. Despite that there are previous studies that address customer knowledge management with regards to its implications for business and projects [49-53], the necessity emerges of conducting further research in the creative industry domain [54]. In fact, although previous studies have investigated the specific benefits of applying customer knowledge management in the creative industry domain, these contributions do not investigate the specific technical and technological capabilities supporting firms to achieve these benefits [55]. In more detail, previous research suggested that in SMEs 
belonging to creative industries the processes of the acquisition, storage and transfer of knowledge should leverage on knowledge nature that is mainly human-embodied through experience and extends to more institutionally-embodied knowledge where the organization's members develop capabilities through the integration of technological tools and organizational approaches [56,57]. In this context, digital technologies can support SMEs operating in creative industries to manage customer knowledge.

Moving to the technology-based customer knowledge management domain (Table 1), where relational tools are communication (e.g., email, blog, content management system) and the collaborative tools (e.g., social media) used to share knowledge and manage the relationships with customers that represent an active part in the communication process [58-60]. Zahay and Handfield (2004) analysed the use of a "shoppable Internet catalogue" developed with the customer [61]. Hsu et al. (2013) illustrated how the adoption of e-voting tools improves companies brand image and also increases customer satisfaction [62]. Syuhada and Gambett (2013) and Govender (2013) analysed the impact of social media on marketing strategies for micro-firms, whereas Pentina and Koh (2012), Durkin et al. (2013), Öztamur and Karakadılar (2014) and Nobre and Silva (2014) focused on small and medium ones [63-68]. Recent studies stated that the conversations among social media users have a great impact on their evaluation and demand [69]. Tussyadiah and Fesenmaier (2008), Cobe (2008) and Chen and Lin (2015) demonstrated the substantial potential of blogs for marketing strategies [70-72]. Yu et al. (2008), Ngu et al. (2010) and Patel et al. (2015) provided an overview of current trends of mash-up adoption [73-75].

Table 1. Papers dealing with the digital technologies supporting customer knowledge management strategies.

\begin{tabular}{cc}
\hline Digital Technologies & References \\
\hline Al-Mutawah et al. (2009); Chen and Lin (2015); Choundary (2013); Cobe \\
(2008); Dotsika and Patrick (2013); Douligeris and Tilipakis (2006); \\
Durkin et al. (2013); Edvardsson (2009); Goel et al. (2005); Govender, \\
2013; Grace (2009); Gresty (2013); Hsu et al. (2013); Huang and Lin \\
(2010); Liu and Lopez (2014); Lopez-Nicolas and Soto-Acosta (2010); \\
Malhotra et al. (2007); Ngu et al. (2010); Nobre and Silva (2014); \\
Öztamur and Karakadilar (2014); Patel et al. (2015); Pentina and Koh \\
(2012); Razmerita and Kirchner (2011); Rosu et al. (2009); Shih et al. \\
(2012); Syuhada and Gambett (2013); Tussyadiah and Fesenmaier (2008); \\
Wu (2001); Yu et al. (2008); Zahay and Handfield (2004) \\
An and Stern (2011); Blois (1999); Briggs and Hollis (1997); Cheung \\
(2008); Drèze and Hussherr (2003); Duffy (2005); Emiliani (2000); \\
Gosselin and Poitras (2008); Gross (2011); Hoffman and Novak (2000); \\
Huang et al. (2009); Johnston (1999); Kim and Lee (2015); Lohtia et al. \\
(2003); Mallinckrodt and Mizerski (2007); Manchanda et al. (2006); \\
Mariussen et al. (2010); Patterson (1997) \\
Marketing Tools \\
Dou et al. (2010); Ghose and Yang (2009); Goldfarb and Tucker (2011); \\
Murphy and Kielgast (2008); Nasomyont and Wisitpongphan (2014); \\
O’Neill and Curran (2011); Sen (2005); Shih et al. (2013); Yang and \\
Ghose (2010)
\end{tabular}

Marketing tools are banner advertising, mobile advertising and direct email marketing used in CKM to share knowledge and manage the passive role of customers that are subjected to communication processes [76-78]. Briggs and Hollis (1997), Drèze and Hussherr (2003), Lohtia et al. (2003) and Manchanda et al. (2006) analysed the use of banner advertising [76-79]. Kim and Lin (2015) focused on mobile advertising in terms of the impact maximisation through targeted marketing based on the customer needs [80]. Gosselin and Poitras (2008), Cheung (2008) and Huang et al. (2009) described direct the adoption of email marketing whereas Hoffman and Novak (2000), Duffy (2005) and Mariussen et al. (2010) focused their attention on affiliate marketing [81-86]. Mallinckrodt and Mizerski (2007), Gross (2010) and An and Stern (2011) investigated the impact of advergames on 
children-oriented marketing [87-89]. Patterson (1997), Blois (1999), Johnston (1999) and Emiliani (2000) investigated the influence of both business-to-business (B2B) and business-to-customer (B2C) on customer satisfaction [90-93].

Search optimisation tools represent the set of sponsoring activities made by a third service organization that focus their attention on a correlation between search engine optimisation (SEO) or search engine marketing (SEM) tools and the rank in search engine result pages (e.g., Google, Bing, Yahoo!) [94-103]. O'Neill and Curran (2011), Shih et al. (2013) and Nasomyont and Wisitpongphan (2014) focused their attention on search engine optimisation (SEO) [94-96], whereas Sen (2005), Murphy and Kielgast (2008) and Dou et al. (2010) analysed the use of search engine marketing (SEM) tools [97-99]. Ghose and Yang (2009), Yang and Ghose (2010) and Goldfarb and Tucker (2011) [100-102] showed the opportunity offered by search engine advertising as a tool to advertise websites in search engines.

In summary, previous contributions have focused on specific relational tools (29), marketing tools (18) and search optimisation tools (9), but did not offer a comprehensive overview of their adoption by SMEs. There is a therefore a clear need for a deeper analysis of the digital technologies used by SMEs in the field of customer knowledge management. The above literature gap allows us to formulate the following research question (RQ):

$R Q:$ What are the main digital technologies supporting SMEs operating in creative industries in their customer knowledge management strategies?

In order to provide an answer to the above research question, the following section provides an overview of the unit of analysis in which the survey was conducted.

\section{The Unit of Analysis}

The analysis was conducted in a sample of 73 firms operating in Campania (Southern Italy). The sampling strategy adopted was the judgment sampling, a non-probability-based sampling method. According to Malhotra, Birks and Wills (2013), in non-probability judgmental sampling, the authors choose the sample group based on their judgments and preferences in order to address the purpose of the study. Considering the specific sector analysed, we employed this sampling technique since a limited number of enterprises operated in the context of investigation.

Regarding data collection, the survey was conducted in a web-based mode. The final sample comprised micro, small and medium firms (European Commission, 2005. The New SME Definition. User Guide and Model Declaration. DG Enterprise \& Industry, Bruxelles) operating in luxury jewellery handicraft and/or retail, as well as 17 firms operating in other industries out of the scope of research (food, security, tourism, etc.). The total employment was about 2000 people and the total turnover was around 300,000 Euros in 2016.

Table 2 shows that most of the firms belonging to the sample operated in the retail industry (46 firms); 19 firms operated in both the handicraft and the retail industries; finally, there were eight handicraft firms that were not retailers.

Table 2. Firm industries.

\begin{tabular}{ccc}
\hline Overall Economic Industry & Number of Firms & $\mathbf{\%}$ \\
\hline Handicraft & 8 & 10.96 \\
Retail & 46 & 63.01 \\
Handicraft/Retail & 19 & 26.03 \\
Total & $\mathbf{7 3}$ & $\mathbf{1 0 0}$ \\
\hline
\end{tabular}

\section{Methodology}

The spread of world wide web significantly increased the number of easily accessible documents and information related to companies. In this context, the potential of document analysis, which aims at extracting symbolic and structured information from online sources, represents a novel and attractive methodology of investigation. In this paper, a two-phase methodology to conduct a field 
analysis involving SMEs operating in creative industries was adopted (Appendix A). These phases are summarised below:

- Data search and collection. In this phase, company websites and other relevant sources were identified and analysed to collect information about the adoption of digital technologies supporting customer knowledge management strategies. All the relevant data were collected in a shared database and cross-checked by all the researchers [103,104].

- Confirmatory analysis. In this phase, the information collected in the previous step was confirmed and/or supplemented by interviews to ensure the reliability of the results $[105,106]$.

The methodology was conducted through the following five steps:

I. Defining survey objectives, in which the basic aims were identified;

II. Defining the draft list of digital technologies supporting customer knowledge management, in which a first list was prepared using the tools identified in the body of literature;

III. Establishing focus group, in which KM experts with different competences were involved to define the list of tools;

IV. Testing the survey on the unit of analysis, in which was conducted a pilot field analysis of five SMEs to integrate the final list;

$\mathrm{V}$ Implementing survey, in which was conducted a comprehensive analysis of the SMEs' webpages and information from phone calls and/or complementary sources were collected and analysed.

\section{Presentation of Findings}

This section reports the set of digital technologies emerging from the literature review findings on the topic of customer knowledge management and adapted to the unit of analysis. Specifically, a draft list of tools was obtained by adapting those proposed in the literature (see II step of methodology). Afterwards, this draft list was submitted to a number of KM experts (see III step of methodology). The feedbacks received and the pilot test of the survey were used to develop a final list (see IV step of methodology). The digital technologies included in the final list were divided into relational tools, marketing tools and search optimisation tools.

The percentage of use of each digital technology supporting the surveyed firms in their customer knowledge management strategies was evaluated. With regard to the relational tools, Figure 1 highlights that their percentage of use ranged from 1.75\% (audio conference/video conference and e-voting) to $76.96 \%$ (e-mail), with a mean equal to $24.74 \%$. The high value of the variance indicated that the intensity of use of relational tools by the selected firms were very spread out around the mean and from each other. 


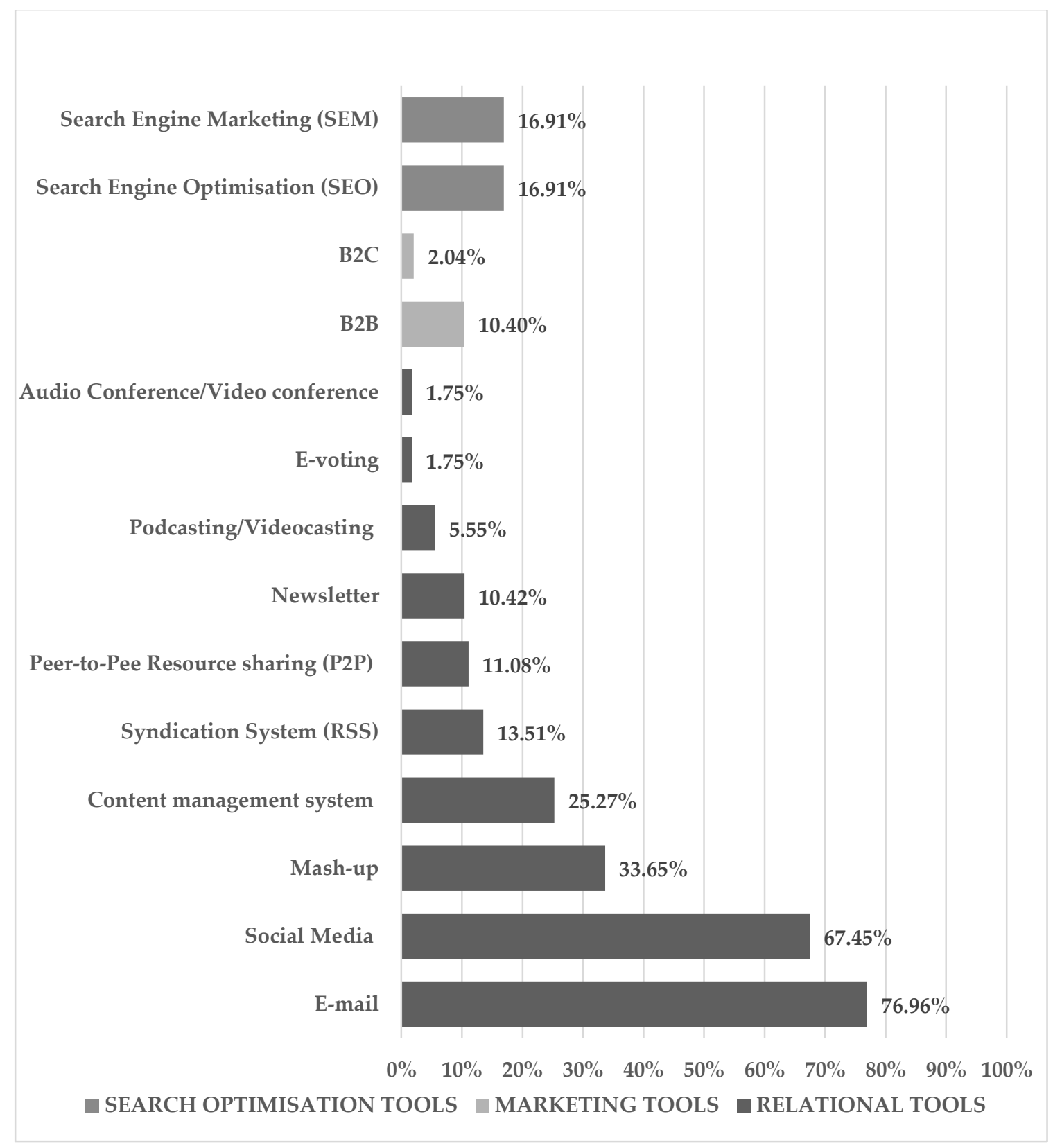

Figure 1. Percentage of adoption of the digital technologies supporting small and medium enterprises (SMEs) in customer knowledge management.

A first group of relational tools adopted with a percentage higher than $50 \%$ included e-mail $(76.96 \%)$ and social media $(67.45 \%)$. As two of the most widespread and popular tools, they represented a fast way for customers to contact firms and ask questions. Moreover, these two tools did not require advanced skills for users and had a time and cost of adoption close to zero.

Table 3 highlights how the different tools were used by SMEs belonging to the different sectors. Handicraft and handicraft and retailer sectors tended to adopt e-mail ( $87.50 \%$ and $84.21 \%$, respectively) instead of social media $(62.50 \%$ and $68.42 \%)$, while on the contrary retailers showed a more intense use of social media (71.43\%) than e-mail (59.18\%).

A second group of relational tools with a percentage of adoption between $10 \%$ and $40 \%$ included mash-up (33.65\%), content management systems $(25.27 \%)$, syndication systems (13.51\%), peer-to-peer resource sharing $(11.08 \%)$ and newsletters $(10.42 \%)$. Excluding newsletters and peer-to-peer resource sharing, the latter are tools whose adoption requires more advanced skills. This group of tools has 
the same distribution among the three different sectors except for newsletters that are not used by handicraft. A third group of relational tools adopted with a percentage lower than $10 \%$ included podcasting/videocasting (5.55\%), audio conference/video conference (1.75\%) and e-voting $(1.75 \%)$. Although the above tools have a very low cost of adoption and require basic skills, they were scarcely adopted by the surveyed SMEs. Focusing on the specific sectors, the results showed that only handicraft and retailer SMEs adopted these tools, even though the percentage was low (5.26\%).

As for marketing tools, business-to-business (B2B) were used with a percentage of $10.40 \%$ followed by the business-to-customer (B2C) with $2.04 \%$. Specifically, the marketing tools used by the surveyed SMEs were the online marketplace, which allows firms to create profiles and sell products to customers or to other firms (respectively B2C or B2B). Product information is provided by the firm, but transactions are processed by the marketplace. The majority of surveyed SMEs adopted eBay, which is one of the most adopted marketplaces in Italy.

Table 4 highlights how the B2B solution was equally distributed among retailer, handicraft and handicraft and retailer, even though B2C solutions were used exclusively by retailer enterprises.

Concerning search optimisation tools, search engine optimisation (SEO) and search engine marketing (SEM) were adopted by $16.91 \%$ of surveyed SMEs.

Table 5 highlights how SEO tools and SEM tools were preferred in customer-oriented firms as retailer and handicraft and retailer (with $22.45 \%$ and $15.79 \%$ ).

In summary, as for relational tools, this paper highlighted that the majority of investigated firms adopted only one digital technology to support customer knowledge management strategies. Regarding marketing tools, these findings seemed to point out that the surveyed SMEs scarcely adopted the few digital technologies represented by marketplaces, but all the firms neglected other tools identified in the literature, such as direct email marketing, banner advertising, affiliate marketing and advergames.

Finally, concerning search optimisation tools, the selected SMEs tended to adopt search engine optimisation (SEO) and search engine marketing (SEM).

These results showed that the investigated SMEs made more intensive use of traditional digital technologies supporting customer knowledge management processes, rather than more innovative digital technologies, despite the latter being generally cheaper, more user-friendly and more effective [30,32-34]. Furthermore, the differences between the handicraft and the retailer sectors were linked with the nature of the sectors. Companies belonging to handicraft sectors were on average more inclined to adopt more formal digital tools (e.g., the e-mail), whereas retailers tended to adopt more informal tools (e.g., the social media) considering that customer knowledge from tacit sources is becoming an important organizational asset [57]. The results highlighted that customer knowledge in handicraft companies was more explicit in nature and embedded in specific know-hows and routines. On the contrary, customer knowledge managed by retail companies tended to be more tacit in nature and mainly embodied in organisational members. Companies belonging to the handicraft and retailer sector were in the middle of these two behaviours, but they were on average more inclined to adopt formalised tools showing a more explicit customer knowledge identity.

The proposed results were in line with the previous study by Centobelli et al. (2019) [12], in which it was assumed that the relational tools, marketing tools and search optimisation tools supported firms to manage knowledge in the different processes of knowledge creation, storage and transfer. For instance, as for the relational tools, mash-up and syndication systems can support firms in customer knowledge creation processes, content management system can support customer knowledge storage, whereas other digital technologies (e.g., e-mail, social media, peer-to-peer resource sharing, podcasting/videocasting, audio conference/video conference) can support customer knowledge transfer. 
Table 3. Percentage of adoption of the relational tools by firm sector.

\begin{tabular}{|c|c|c|c|c|c|c|c|c|c|c|c|}
\hline & E-Mail & $\begin{array}{l}\text { Social } \\
\text { Media }\end{array}$ & Mash-Up & $\begin{array}{c}\text { Content } \\
\text { Management } \\
\text { System }\end{array}$ & $\begin{array}{l}\text { Syndication } \\
\text { System } \\
\text { (RSS) }\end{array}$ & $\begin{array}{c}\text { Peer-to-Peer } \\
\text { Resource } \\
\text { Sharing (P2P) }\end{array}$ & Newsletter & $\begin{array}{c}\text { Podcasting } \\
\text { Videocasting }\end{array}$ & E-Voting & $\begin{array}{c}\text { Audio } \\
\text { Conference Video } \\
\text { Conference }\end{array}$ & $\begin{array}{l}\text { Relational } \\
\text { Tools }\end{array}$ \\
\hline Retailer & $59.18 \%$ & $71.43 \%$ & $28.57 \%$ & $24.49 \%$ & $12.24 \%$ & $10.20 \%$ & $10.20 \%$ & $6.12 \%$ & $0.00 \%$ & $0.00 \%$ & $22.24 \%$ \\
\hline Handicraft & $87.50 \%$ & $62.50 \%$ & $25.00 \%$ & $25.00 \%$ & $12.50 \%$ & $12.50 \%$ & $0.00 \%$ & $0.00 \%$ & $0.00 \%$ & $0.00 \%$ & $22.50 \%$ \\
\hline $\begin{array}{c}\text { Handicraft } \\
\text { and Retailer }\end{array}$ & $84.21 \%$ & $68.42 \%$ & $47.37 \%$ & $26.32 \%$ & $15.79 \%$ & $10.53 \%$ & $21.05 \%$ & $10.53 \%$ & $5.26 \%$ & $5.26 \%$ & $29.47 \%$ \\
\hline
\end{tabular}


Table 4. Percentage of adoption of the marketing tools by firm sector.

\begin{tabular}{cccc}
\hline & B2B & B2C & Marketing Tools \\
\hline Retailer & $8.16 \%$ & $6.12 \%$ & $\mathbf{7 . 1 4 \%}$ \\
\hline Handicraft & $12.50 \%$ & $0.00 \%$ & $\mathbf{6 . 2 5 \%}$ \\
\hline Handicraft and Retailer & $10.53 \%$ & $0.00 \%$ & $\mathbf{5 . 2 6 \%}$ \\
\hline
\end{tabular}

Table 5. Percentage of adoption of the search optimisation tools by firm sector.

\begin{tabular}{cccc}
\hline & $\begin{array}{c}\text { Search Engine } \\
\text { Optimisation (SEO) }\end{array}$ & $\begin{array}{c}\text { Search Engine } \\
\text { Marketing (SEM) }\end{array}$ & $\begin{array}{c}\text { Search Optimisation } \\
\text { Tools }\end{array}$ \\
\hline Retailer & $22.45 \%$ & $22.45 \%$ & $\mathbf{2 2 . 4 5 \%}$ \\
\hline Handicraft & $12.50 \%$ & $12.50 \%$ & $\mathbf{1 2 . 5 0 \%}$ \\
\hline Handicraft and Retailer & $15.79 \%$ & $15.79 \%$ & $\mathbf{1 5 . 7 9 \%}$ \\
\hline
\end{tabular}

\section{Conclusions and Implications}

The main aim of this paper was to investigate the digital technologies supporting SMEs operating in creative industries in their customer knowledge management strategies. According to the body of literature on the topic, the main digital technologies adopted in the customer knowledge management domain were divided into three groups: (1) relational tools, (2) marketing tools and (3) search optimisation tools. As for the relational tools, it emerged that firms generally used traditional digital technologies. This aspect was a managerial implication for information technology vendors to capture the attractiveness of the increasing market represented by SMEs. On the other hand, it was a policy implication to support SMEs, which need financial incentives for their technological and digital innovation. Concerning the marketing tools, this paper highlighted that the surveyed SMEs leveraged on marketplaces. Nevertheless, it also emerged that in this case SMEs tended to not adopt more updated tools (e.g., direct email marketing, banner advertising, affiliate marketing, advergames). Regarding the search optimisation tools, the paper seemed to point out that a major percentage of the investigated SMEs tended to adopt SEO and SEM.

This paper highlighted that the surveyed SMEs adopted and made more intensive use of traditional technologies supporting customer knowledge management processes rather than more innovative digital technologies, despite the latter being generally cheaper, more user-friendly and more effective. This result was in line with the previous studies by Centobelli et al. (2016) [31], in which it was assumed that SMEs typically did not have dedicated resources to monitor the evolution of the digital market and were not even able to follow technological dynamics, and these aspects forced them to remain in a backward position. Furthermore, the results were in line with the previous literature on KM in SMEs showing that small and medium enterprises were not simply a scaled-down replica of large firms and behaved like entities without a strategy of their own for addressing the processes of customer knowledge management [20,31,107-110].

As for the main theoretical implications, this research paved the way for further and in-depth analysis concerning the recent technological and managerial evolution of knowledge management systems [12,111,112]. In fact, KMSs are becoming a combination of knowledge management tools, namely specific IT-based systems supporting knowledge management processes, and knowledge management practices, which are defined as methods and techniques to support the organisational processes of knowledge management. Therefore, according to the previous results proposed by Carayannis (1999) and Centobelli et al. (2019) [12,113], in which it was assumed that KM played a crucial role in fostering a synergistic symbiosis between technological capabilities and managerial/organizational practices, the necessity emerged of analysing the degree of alignment between the tools and practices supporting CKM processes. 
As for the practical implications, the differences between SMEs and large companies, in terms of size, structure and processes, lead them to be completely different in knowledge management processes and also in the way customer knowledge is managed. However, in many industries, SMEs represent a significant percentage of companies. Therefore, to catch this opportunity, it is necessary to strengthen the link between KMS providers and companies with direct channels and create new market segments dedicated to SMEs to offer them digital solutions tailored to their businesses.

As for the future directions, future research can conduct secondary document analysis to investigate the degree of adoption of the digital technologies investigated in this paper in order to extend and enhance the generalisation of these findings.

\section{Limitations}

This research was based on the empirical analysis of SMEs operating in creative industries that had the scope to be tested in different contexts. Therefore, future research needs to extend these results.

Author Contributions: P.C. and R.C. conceived and designed the paper; F.C., P.C., R.C., E.E., E.O. and R.P. conducted scientific literature review, analysed and interpreted the data; R.C. supervised the work. Authors are listed in alphabetical order. All authors have read and agreed to the published version of the manuscript.

Funding: This research received no external funding.

Conflicts of Interest: The authors declare no conflict of interest.

\section{Appendix A}

\section{Managing Customer Knowledge}

This survey aims to collect information about the adoption of digital technologies supporting customer knowledge management strategies in creative industries. The questionnaire consists of two main sections. Section 1 includes general information about the company. Section 2 includes a list of tools for which it is asked to tick a box to specify if it was used or not.

\section{General information about the company}

Name of company:

\section{Address:}

Main industry:

Number of employees:

2. Digital technologies supporting customer knowledge management strategies (Relational Tools, Marketing Tools and Search Optimisation Tools)

Tick the box if the company uses one or more of the following tools (multiple choice is allowed)

\begin{tabular}{|l|l|l|}
\hline \multirow{2}{*}{ Relational Tools } & Yes & No \\
\hline & 1 & 0 \\
\hline Social Media & $\square$ & $\square$ \\
\hline E-mail & $\square$ & $\square$ \\
\hline Mash-up & $\square$ & $\square$ \\
\hline Content Management Systems (CMS) & $\square$ & $\square$ \\
\hline Syndication Systems (RSS) & $\square$ & $\square$ \\
\hline Newsletter & $\square$ & $\square$ \\
\hline Peer-to-Peer Resource Sharing (P2P) & $\square$ & $\square$ \\
\hline Podcasting/Videocasting & $\square$ & $\square$ \\
\hline Audio Conference/Video Conference & $\square$ & $\square$ \\
\hline E-voting & $\square$ & $\square$ \\
\hline Other (please specify) & & \\
\hline
\end{tabular}




\begin{tabular}{|c|c|c|}
\hline \multirow{2}{*}{ Marketing Tools } & Yes & No \\
\hline & 1 & 0 \\
\hline Business-to-Business (B2B) & $\square$ & $\square$ \\
\hline Business-to-Business (B2C) & $\square$ & $\square$ \\
\hline \multicolumn{3}{|l|}{ Other (please specify) } \\
\hline \multirow{2}{*}{ Search Optimisation Tools } & Yes & No \\
\hline & 1 & 0 \\
\hline Search Engine Optimisation (SEO) & $\square$ & $\square$ \\
\hline Search Engine Marketing (SEM) & $\square$ & $\square$ \\
\hline Other (please specify) & & \\
\hline
\end{tabular}

\section{References}

1. Raguseo, E.; Vitari, C. Investments in big data analytics and firm performance: An empirical investigation of direct and mediating effects. Int. J. Prod. Res. 2018, 56, 5206-5221. [CrossRef]

2. Saldanha, T.J.; Melville, N.P.; Ramirez, R.; Richardson, V.J. Information systems for collaborating versus transacting: Impact on manufacturing plant performance in the presence of demand volatility. J. Oper. Manag. 2013, 31, 313-329. [CrossRef]

3. Saldanha, T.J.V.; Mithas, S.; Krishnan, M.S. Leveraging Customer Involvement for Fueling Innovation: The Role of Relational and Analytical Information Processing Capabilities. MIS Q. 2017, 41, 367-396. [CrossRef]

4. Berger, E.S.; Kuckertz, A. Female entrepreneurship in startup ecosystems worldwide. J. Bus. Res. 2016, 69, 5163-5168. [CrossRef]

5. Nambisan, S.; Lyytinen, K.; Majchrzak, A.; Song, M. Digital Innovation Management: Reinventing Innovation Management Research in a Digital World. MIS Q. 2017, 41, 223-238. [CrossRef]

6. Escribano, A.; Fosfuri, A.; Tribo, J.A. Managing external knowledge flows: The moderating role of absorptive capacity. Res. Policy 2009, 38, 96-105. [CrossRef]

7. Laursen, K.; Salter, A. Open for innovation: The role of openness in explaining in-novation performance among U.K. manufacturing firms. Strateg. Manag. J. 2006, 27, 131-150. [CrossRef]

8. Mazzola, E.; Bruccoleri, M.; Perrone, G. The effect of Inbound, Outbound, and Coupled Open Innovation practices on firm performance: Empirical evidences from bio-pharmaceutical industry. Int. J. Technol. Manag. 2016, 70, 2-3. [CrossRef]

9. Natalicchio, A.; Ardito, L.; Savino, T.; Albino, V. Managing knowledge assets for open innovation: A systematic literature review. J. Knowl. Manag. 2017, 21, 1362-1383. [CrossRef]

10. Passaro, R.; Quinto, I.; Thomas, A.; Chase, R.; Secundo, G. The impact of higher education on entrepreneurial intention and human capital. J. Intellect. Cap. 2018, 19, 135-156. [CrossRef]

11. Trantopoulos, K.; Von Krogh, G.; Wallin, M.; Woerter, M. External Knowledge and Information Technology: Implications for Process Innovation Performance. MIS Q. 2017, 41, 287-300. [CrossRef]

12. Centobelli, P.; Cerchione, R.; Esposito, E. Efficiency and effectiveness of knowledge management systems in SMEs. Prod. Plan. Control. 2019, 30, 779-791. [CrossRef]

13. Ekbia, H.R. Digital artifacts as quasi-objects: Qualification, mediation, and materiality. J. Am. Soc. Inf. Sci. Technol. 2009, 60, 2554-2566. [CrossRef]

14. Lyytinen, K.; Yoo, Y.; Boland, R.J. Digital product innovation within four classes of innovation networks. Inf. Syst. J. 2015, 26, 47-75. [CrossRef]

15. Tiwana, A.; Konsynski, B.R.; Bush, A.A. Research Commentary-Platform Evolution: Coevolution of Platform Architecture, Governance, and Environmental Dynamics. Inf. Syst. Res. 2010, 21, 675-687. [CrossRef]

16. Saini, A.; Grewal, R.; Johnson, J.L. Putting market-facing technology to work: Organizational drivers of CRM performance. Mark. Lett. 2009, 21, 365-383. [CrossRef]

17. Malhotra, N.K.; Birks, D.F.; Wills, P. Essentials of Marketing Research; Pearson: Essex, UK, 2013.

18. Latilla, V.M.; Frattini, F.; Petruzzelli, A.M.; Berner, M. Knowledge management, knowledge transfer and organizational performance in the arts and crafts industry: A literature review. J. Knowl. Manag. 2018, 22, 1310-1331. [CrossRef] 
19. Venkitachalam, K.; Busch, P. Tacit knowledge: Review and possible research directions. J. Knowl. Manag. 2012, 16, 357-372. [CrossRef]

20. DeSouza, K.; Awazu, Y. Knowledge management at SMEs: Five peculiarities. J. Knowl. Manag. 2006, 10, 32-43. [CrossRef]

21. Lampel, J.; Germain, O. Creative industries as hubs of new organizational and business practices. J. Bus. Res. 2016, 69, 2327-2333. [CrossRef]

22. Seltzer, K.; Bentley, T. The Creative Age: Knowledge and Skills for the New Economy; Demos: London, UK, 1999.

23. Gil-Gomez, H.; Guerola-Navarro, V.; Oltra-Badenes, R.; Lozano-Quilis, J.A. Customer relationship management: Digital transformation and sustainable business model innovation. Economic ResearchEkonomska Istraživanja 2020, 1-18. [CrossRef]

24. Alegre, J.; Sengupta, K.; Lapiedra, R. Knowledge management and innovation performance in a high-tech SMEs industry. Int. Small Bus. J. Res. Entrep. 2011, 31, 454-470. [CrossRef]

25. Chua, A.Y.K.; Banerjee, S. Customer knowledge management via social media: The case of Starbucks. J. Knowl. Manag. 2013, 17, 237-249. [CrossRef]

26. Pil, F.; Holweg, M. Exploring Scale-The Advantages of Thinking Small. MIT Sloan Manag. Rev. 2003, 43, 33-39.

27. Eisenhardt, K.M.; Martin, J.A. Dynamic capabilities: What are they? Strateg. Manag. J. 2000, 21, 1105-1121. [CrossRef]

28. Lusch, R.F.; Vargo, S.; O’Brien, M. Competing through service: Insights from service-dominant logic. J. Retail. 2007, 83, 5-18. [CrossRef]

29. Prahalad, C.; Ramaswamy, V. Co-creation experiences: The next practice in value creation. J. Interact. Mark. 2004, 18, 5-14. [CrossRef]

30. Antonelli, C.; Geuna, A.; Steinmueller, W.E. Information and communication technologies and the production, distribution and use of knowledge. Int. J. Technol. Manag. 2000, 20, 72. [CrossRef]

31. Centobelli, P.; Cerchione, R.; Esposito, E.; Raffa, M. Digital Marketing in SMEs: The Impact of Web-based Technologies. Adv. Sci. Lett. 2016, 22, 1473-1476. [CrossRef]

32. Esposito, E.; Mastroianni, M. Information technology and personal computers: The relational life cycle. Technovation 2002, 22, 41-50. [CrossRef]

33. Matlay, H.; Westhead, P. Virtual Teams and the Rise of e-Entrepreneurship in Europe. Int. Small Bus. J. Res. Entrep. 2005, 23, 279-302. [CrossRef]

34. Garrigos-Simon, F.J.; Alcamí, R.L.; Ribera, T.B. Social networks and Web 3.0: Their impact on the management and marketing of organizations. Manag. Decis. 2012, 50, 1880-1890. [CrossRef]

35. Lopez-Nicolas, C.; Molina-Castillo, F.-J. Customer Knowledge Management and E-commerce: The role of customer perceived risk. Int. J. Inf. Manag. 2008, 28, 102-113. [CrossRef]

36. Rollins, M.; Halinen, A. Customer Knowledge Management Competence: Towards a Theoretical Framework. In Proceedings of the 38th Annual Hawaii International Conference on System Sciences, Big Island, HI, USA, 6 January 2005; p. 240.

37. Pittaway, L.; Robertson, M.; Munir, K.; Denyer, D.; Neely, A.; Neely, A.D. Networking and innovation: A systematic review of the evidence. Int. J. Manag. Rev. 2004, 5, 137-168. [CrossRef]

38. Petticrew, M.; Roberts, H. Systematic Reviews in the Social Sciences, 1st ed.; Blackwell Publishing: Malden, MA, USA, 2006.

39. Easterby-Smith, M.; Thorpe, R.; Jackson, P. Management Research; SAGE Publications: London, UK, 2012.

40. Garc, H.A.M. Customer knowledge management. J. Oper. Res. Soc. 2002, 53, 875-884. [CrossRef]

41. Srikantaiah, T.; Koenig, M.E.D.; American Society for Information Science. Knowledge Management for the Information Professional; Information Today: Medford, NJ, USA, 2000.

42. Butler, Y. Knowledge management-If only you knew what you knew. Aust. Libr. J. 2000, 49, 31-43. [CrossRef]

43. Davenport, T.H.; Harris, J.; Kohli, A. How Do They Know Their Customers so Well? MIT Sloan Manag. Rev. 2001, 42, 63.

44. Gibbert, M.; Leibold, M.; Probst, G. Five Styles of Customer Knowledge Management, and How Smart Companies Use Them To Create Value. Eur. Manag. J. 2002, 20, 459-469. [CrossRef]

45. Bell, W.; Toffler, A. The Third Wave. Soc. Forces 1982, 61, 298. [CrossRef] 
46. Thomke, S.; Hippel, E. Customers as Innovators: A New Way to Create Value. Harvard Bus. Rev. 2002, 80, 74-85.

47. Sawhney, M.; Prandelli, E. Communities of Creation: Managing Distributed Innovation in Turbulent Markets. Calif. Manag. Rev. 2000, 42, 24-54. [CrossRef]

48. Rowley, J. Information marketing in a digital world. Libr. Hi Tech. 2002, 20, 352-358. [CrossRef]

49. Abid, M.; Ali, B. Antecedents and effectiveness of CKM: An empirical study. Middle East J. Sci. Res. 2014, 19, 880-892. [CrossRef]

50. Gorry, G.A.; Westbrook, R.A. Customers, knowledge management, and intellectual capital. Knowl. Manag. Res. Pract. 2013, 11, 92-97. [CrossRef]

51. Lin, R.-J.; Che, R.-H.; Ting, C.-Y. Turning knowledge management into innovation in the high-tech industry. Ind. Manag. Data Syst. 2012, 112, 42-63. [CrossRef]

52. Sayed Soliman, H. Customer Relationship Management and Its Relationship to the Marketing Performance. Int. J. Bus. Soc. Sci. 2011, 2, 166-182.

53. Sofianti, T.D.; Suryadi, K.; Govindaraju, R.; Prihartono, B. Measuring productivity of customer knowledge management in projects. Knowl. Manag. E-Learn. Int. J. 2013, 5, 186-204. [CrossRef]

54. Fidel, P.; Schlesinger, W.; Emilo, E. Effects of customer knowledge management and customer orientation on innovation capacity and marketing results in SMEs: The mediating role of innovation orientation. Int. J. Innov. Manag. 2018, 22, 1850055. [CrossRef]

55. Zhan, Y.; Tan, K.H.; Huo, B. Bridging customer knowledge to innovative product development: A data mining approach. Int. J. Prod. Res. 2019, 57, 6335-6350. [CrossRef]

56. Centobelli, P.; Ndou, V. Managing customer knowledge through the use of big data analytics in tourism research. Curr. Issues Tour. 2019, 22, 1862-1882. [CrossRef]

57. He, W.; Zhang, W.; Tian, X.; Tao, R.; Akula, V. Identifying customer knowledge on social media through data analytics. J. Enterp. Inf. Manag. 2019, 32, 152-169. [CrossRef]

58. Choundhary, A.I.; Akhtar, S.A.; Zaheer, A. Impact of transformational and servant leadership on organisational performance: A comparative analysis. J. Bus. Ethics 2013, 116, 433-440. [CrossRef]

59. Gresty, M. What role do information systems play in the knowledge management activities of SMEs? Bus. Inf. Rev. 2013, 30, 144-151. [CrossRef]

60. Dotsika, F.; Patrick, K. Collaborative KM for SMEs: A framework evaluation study. Inf. Technol. People 2013, 26, 368-382. [CrossRef]

61. Zahay, D.L.; Handfield, R.B. The role of learning and technical capabilities in predicting adoption of B2B technologies. Ind. Mark. Manag. 2004, 33, 627-641. [CrossRef]

62. Hsu, C.-C.; Tan, K.C.; Zailani, S.H.M.; Jayaraman, V. Supply chain drivers that foster the development of green initiatives in an emerging economy. Int. J. Oper. Prod. Manag. 2013, 33, 656-688. [CrossRef]

63. Syuhada, A.A.; Gambett, W. Online Marketplace for Indonesian Micro Small and Medium Enterprises based on Social Media. Procedia Technol. 2013, 11, 446-454. [CrossRef]

64. Govender, J.P. Using the Internet to market small, medium and micro enterprises in a developing economy. Probl. Perspect. Manag. 2013, 11, 20-27.

65. Pentina, I.; Koh, A.C. Exploring social media marketing strategies in SMEs. Int. J. Internet Mark. Advert. 2012, 7, 292. [CrossRef]

66. Durkin, M.; McGowan, P.; McKeown, N. Exploring social media adoption in small to medium-sized enterprises in Ireland. J. Small Bus. Enterp. Dev. 2013, 20, 716-734. [CrossRef]

67. Öztamur, D.; Karakadılar, I.S. Exploring the Role of Social Media for SMEs: As a New Marketing Strategy Tool for the Firm Performance Perspective. Procedia Soc. Behav. Sci. 2014, 150, 511-520. [CrossRef]

68. Nobre, H.; Silva, D. Social Network Marketing Strategy and SME Strategy Benefits. J. Transnatl. Manag. 2014, 19, 138-151. [CrossRef]

69. Liu, Y.; Lopez, R.A. The impact of social media conversations on consumer brand choices. Mark. Lett. 2014, 27, 1-13. [CrossRef]

70. Tussyadiah, I.P.; Fesenmaier, D.R. Marketing Places Through First-Person Stories-An Analysis of Pennsylvania Roadtripper Blog. J. Travel Tour. Mark. 2008, 25, 299-311. [CrossRef]

71. Cobe, P. Marketing: Chefs who blog. Restaur. Bus. 2008, 107, 14.

72. Chen, S.-C.; Lin, C.-P. The impact of customer experience and perceived value on sustainable social relationship in blogs: An empirical study. Technol. Forecast. Soc. Chang. 2015, 96, 40-50. [CrossRef] 
73. Yu, J.; Benatallah, B.; Casati, F.; Daniel, F. Understanding Mashup Development. IEEE Internet Comput. 2008, 12, 44-52. [CrossRef]

74. Ngu, A.H.; Carlson, M.P.; Sheng, Q.Z.; Paik, H.-Y. Semantic-Based Mashup of Composite Applications. IEEE Trans. Serv. Comput. 2010, 3, 2-15. [CrossRef]

75. Patel, A.; Al_Janabi, S.; AlShourbaji, I.H.; Pedersen, J.M. A novel methodology towards a trusted environment in mashup web applications. Comput. Secur. 2015, 49, 107-122. [CrossRef]

76. Briggs, R.; Hollis, N. Advertising on the web: Is there response before click-through? J. Advert. Res. 1997, 37, 33-45.

77. Dreze, X.; Hussherr, F.-X. Internet advertising: Is anybody watching? J. Interact. Mark. 2003, 17, 8-23. [CrossRef]

78. Lothia, R.; Donthu, N.; Hershberger, E.K. The Impact of Content and Design Elements on Banner Advertising Click-Through Rates. J. Advert. Res. 2003, 43, 410-418. [CrossRef]

79. Manchanda, P.; Dube, J.-P.; Goh, K.Y.; Chintagunta, P.K. The Effect of Banner Advertising on Internet Purchasing. J. Mark. Res. 2006, 43, 98-108. [CrossRef]

80. Kim, K.Y.; Lee, B.G. Marketing insights for mobile advertising and consumer segmentation in the cloud era: A Q-R hybrid methodology and practices. Technol. Forecast. Soc. Chang. 2015, 91, 78-92. [CrossRef]

81. Gosselin, P.; Poitras, P.; Bonander, J.; Robinson, L. Use of an Internet "Viral" Marketing Software Platform in Health Promotion. J. Med. Internet Res. 2008, 10, e47. [CrossRef]

82. Cheung, M. 'Click here': The impact of new media on the encoding of persuasive messages in direct marketing. Discourse Stud. 2008, 10, 161-189. [CrossRef]

83. Huang, C.-C.; Lin, T.-C.; Lin, K.-J. Factors affecting pass-along email intentions (PAEIs): Integrating the social capital and social cognition theories. Electron. Commer. Res. Appl. 2009, 8, 160-169. [CrossRef]

84. Hoffman, D.L.; Novak, T.P. How to acquire customers on the Web. Harv. Bus. Rev. 2001, 78, 179-188, 218.

85. Duffy, D.L. Affiliate marketing and its impact on e-commerce. J. Consum. Mark. 2005, 22, 161-163. [CrossRef]

86. Mariussen, A.; Daniele, R.; Bowie, D. Unintended consequences in the evolution of affiliate marketing networks: A complexity approach. Serv. Ind. J. 2010, 30, 1707-1722. [CrossRef]

87. Mallinckrodt, V.; Mizerski, D. The effects of playing an advergame on young children's perceptions, preferences, and requests. J. Advert. 2007, 36, 87-100. [CrossRef]

88. Gross, M.L. Advergames and the effects of game-product congruity. Comput. Hum. Behav. 2010, 26, 1259-1265. [CrossRef]

89. An, S.; Stern, S. Mitigating the Effects of Advergames on Children. J. Advert. 2011, 40, 43-56. [CrossRef]

90. Patterson, P.G.; Johnson, L.W.; Spreng, R.A. Modeling the determinants of customer satisfaction for business-to-business professional services. J. Acad. Mark. Sci. 1997, 25, 4-17. [CrossRef]

91. Blois, K.J. Trust in Business to Business Relationships: An Evaluation of its Status. J. Manag. Stud. 1999, 36, 197-215. [CrossRef]

92. Johnston, W.J.; Leach, M.P.; Liu, A.H. Theory Testing Using Case Studies in Business-to-Business Research. Ind. Mark. Manag. 1999, 28, 201-213. [CrossRef]

93. Emiliani, M. Business-to-business online auctions: Key issues for purchasing process improvement. Supply Chain Manag. Int. J. 2000, 5, 176-186. [CrossRef]

94. O'Neill, S.; Curran, K. The Core Aspects of Search Engine Optimisation Necessary to Move up the Ranking. Int. J. Ambient. Comput. Intell. 2011, 3, 62-70. [CrossRef]

95. Shih, S.C.; Hsu, S.H.; Zhu, Z.; Balasubramanian, S.K. Knowledge sharing-A key role in the downstream supply chain. Inf. Manag. 2012, 49, 70-80. [CrossRef]

96. Nasomyont, T.; Wisitpongphan, N. A Study on the Relationship between Search Engine Optimization Factors and Rank on Google Search Result Page. Adv. Mater. Res. 2014, 931, 1462-1466. [CrossRef]

97. Sen, R. Optimal Search Engine Marketing Strategy. Int. J. Electron. Commer. 2005, 10, 9-25. [CrossRef]

98. Murphy, H.C.; Kielgast, C.D. Do small and medium-sized hotels exploit search engine marketing? Int. J. Contemp. Hosp. Manag. 2008, 20, 90-97. [CrossRef]

99. Dou, W.; Lim, K.H.; Su, C.; Cui, N.Z. Brand Positioning Strategy Using Search Engine Marketing. MIS Q. 2010, 34, 261. [CrossRef]

100. Ghose, A.; Yang, S. An empirical analysis of search engine advertising: Sponsored search in electronic markets. Manag. Sci. 2009, 55, 1605-1622. [CrossRef] 
101. Yang, S.; Ghose, A. Analyzing the Relationship Between Organic and Sponsored Search Advertising: Positive, Negative, or Zero Interdependence? Mark. Sci. 2010, 29, 602-623. [CrossRef]

102. Goldfarb, A.; Tucker, C. Search Engine Advertising: Channel Substitution When Pricing Ads to Context. Manag. Sci. 2011, 57, 458-470. [CrossRef]

103. Labuschagne, A. Qualitative Research: Airy Fairy or Fundamental? Qual. Rep. 2003, 8, 100-103.

104. Zhang, Y.; Wildemuth, B.M. Qualitative Analysis of Content. In Applications of Social Research Methods to Applications to Question in Information and Library Science, 2nd ed.; Wilde-Muth, B.M., Ed.; Brooks/Cole: Belmont, CA, USA, 2017; pp. 318-329.

105. Angers, J.; Machtmes, K.L. An Ethnographic-Case Study of Beliefs, Context Factors, and Practices of Teachers Integrating Technology. Qual. Rep. 2005, 10, 771-794.

106. Bowen, G. Document Analysis as a Qualitative Research Method. Qual. Res. J. 2009, 9, 27-40. [CrossRef]

107. Egbu, C.O.; Hari, S.; Renukappa, S.H. Knowledge management for sustainable competitiveness in small and medium surveying practices. Struct. Surv. 2005, 23, 7-21. [CrossRef]

108. Sparrow, J. Knowledge management in small firms. Knowl. Process. Manag. 2001, 8, 3-16. [CrossRef]

109. Wong, K.Y.; Aspinwall, E. An empirical study of the important factors for knowledge-management adoption in the SME sector. J. Knowl. Manag. 2005, 9, 64-82. [CrossRef]

110. Wong, K.Y. Critical success factors for implementing knowledge management in small and medium enterprises. Ind. Manag. Data Syst. 2005, 105, 261-279. [CrossRef]

111. Alavi, M.; Leidner, D. Review: Knowledge Management and Knowledge Management Systems: Conceptual Foundations and Research Issues. MIS Q. 2001, 25, 107. [CrossRef]

112. Fink, K.; Ploder, C. Knowledge Management Toolkit for SMEs. Int. J. Knowl. Manag. 2009, 5, 46-60. [CrossRef]

113. Carayannis, E.G. Fostering synergies between information technology and managerial and organizational cognition: The role of knowledge management. Technovation 1999, 19, 219-231. [CrossRef]

(C) 2020 by the authors. Licensee MDPI, Basel, Switzerland. This article is an open access article distributed under the terms and conditions of the Creative Commons Attribution (CC BY) license (http://creativecommons.org/licenses/by/4.0/). 